\title{
Factors Associated with Persistence of Hepatitis B Virus Infection
}

\section{George Kamkamidze*, Tamar Kikvidze, Maia Butsashvili and Olga Chubinishvili}

Health Research Union, Georgia, USA

\begin{abstract}
Hepatitis B Virus (HBV) infection is a global health problem that is endemic in many parts of the world. 90-95\% of the infected adults can clear the virus. Host genetic factors play a major role in determining the outcome of HBV infection. This study estimated the role of nonfunctional CCR5 receptor (CCR $\Delta 32$ mutation) in the recovery from hepatitis $B$ infection among Georgian patients. Case-control study has been conducted, where study subjects with persistent HBV infection were matched to double number of individuals who had recovered from the HBV infection. The overall number of study subjects was 282 (94 cases and 188 controls). Demographic, medical and behavioral characteristics of the study participants were collected. CCR5 delta32 mutation was evaluated by PCR methodology. The overall prevalence of CCR5 receptor mutation was $13.1 \%(n=37)$. Among controls (HBsAg-) CCR5 receptor mutation was detected in $16.5 \%(n=31)$, in cases - only in $6.4 \%(n=6)$. Cases were 2.58 times less likely to have CCR5 $\Delta 32$ mutation compared to controls (OR $=2.58 ; 95 \% \mathrm{Cl} 1.12,5.98)$. Multivariate analysis revealed CCR5 receptor mutation and alcohol consumption as independent predictors of HBs positivity. The study gives clear evidence that genetic factors (CCR5 receptor mutation) play an important role in Hepatitis B virus persistence together with environmental/behavioral factors, such as the alcohol use.
\end{abstract}

\section{Introduction}

Hepatitis B virus infection is a global health problem that is endemic in many parts of the world. It is one of the most common causes of liver-related sequelae, including cirrhosis, fulminant liver failure, liver transplantation, hepatocellular carcinoma, and death. 90-95\% of the infected adults can clear the virus with only $5-10 \%$ becoming chronic carriers. Among the carriers 20-30\% develops liver cirrhosis and about 5\% develop hepatocellular carcinoma. Persistent or chronic $\mathrm{HBV}$ infection is among the most common persistent viral infections in humans [1].

There is strong epidemiological evidence that host genetic factors play a major role in determining the outcome of HBV infection [2-5]. Some studies were focused on the investigation of the role of CCR5 receptor gene polymorphisms in the course of HBV infection and there are reports documenting the presence of an association between CCR5 receptor and hepatitis B virus infection persistence [6-9]. In different reports there are controversial data regarding the nature of the association of the CCR5 polymorphisms with the natural history, disease severity and antiviral treatment responses [10-14].

CCR5 is a CC chemokine receptor that is expressed on various cell types including Natural Killer (NK) T cells, CD4+ T cells, macrophages, and NK cells. CCR5 is a G-protein coupled receptor known to regulate the immune response by interacting with any of three chemokine ligands (CCL3, CCL4, and CCL5) [15].

In the mid-1990s this receptor was identified as one of the obligate membrane co-receptors for the binding and entry of Human Immunodeficiency (HIV) virus into target cells. Scientists also detected a defective CCR5 allele with 32-basepair deletion (CCR5 $\Delta 32$ ), which provides homozygotes with high resistance against HIV virus infection [16]. CCR5 gene functionally null allele containing a 32-basepair deletion (CCR5 $\Delta 32$ ) has been identified in $10-15 \%$ of Caucasians [17].

In one of our previous studies we have shown that CCR5 delta32 mutation is a predominant alteration of CCR5 gene among Georgians, allelic frequency of this mutation was equal to $5 \%$ [18].

In support of a modulatory role for CCR 5 in hepatic inflammation, the CCR5 delta32 polymorphism has been linked to the prevalence and severity of a number of $\mathrm{T}$ cell-mediated liver diseases including chronic hepatitis and primary sclerosing cholangitis [15].

Epidemiological studies indicate the role of CCR5 receptor in the immune response against hepatitis B virus infection. It has been previously proposed that nonfunctional CCR5 (CCR5 $\Delta 32)$ is associated with recovery from acute Hepatitis $B$ virus infection due to the development of forceful T-cell response [19].

This study estimated the role of nonfunctional CCR5 (CCR $\Delta 32)$ in the recovery from hepatitis $\mathrm{B}$ infection among Georgian patients.

\section{Materials and Methods}

Case-control study has been conducted, where study subjects with persistent $\mathrm{HBV}$ infection were matched to double number of individuals who had recovered from the HBV infection. The overall number of study subjects was 282 (94 cases and 188 controls). Cases were defined as persons having positive $\mathrm{HBsAg}$, while the $\mathrm{HBsAg}$ negative/anti-HBc positive persons were included in the control group.

Testing on HBsAg, antiHBc and antiHBs was done using third generation ELISA method. The person was considered persistently infected with $\mathrm{HBV}$ if their serum or plasma tested positive for hepatitis B surface antigen (HBsAg) at two visits separated by a minimum of 6 months. Individuals who were positive for anti-HBc and anti-HBs without the presence of $\mathrm{HBsAg}$ at two time points separated by a minimum of 6 months were considered as recovered from HBV infection.

*Corresponding author: George Kamkamidze, Health Research Union, 8 Nutsubidze Str. Tbilisi 0177 Georgia, USA, Tel: 995322 144447; E-mail: georgekamkamidze@gmail.com

Received November 20, 2013; Accepted March 29, 2014; Published April 05, 2014

Citation: Kamkamidze G, Kikvidze T, Butsashvili M, Chubinishvili O (2014) Factors Associated with Persistence of Hepatitis B Virus Infection. J Liver 3: 153. doi:10.4172/2167-0889.1000153

Copyright: (C) 2014 Kamkamidze G, et al. This is an open-access article distributed under the terms of the Creative Commons Attribution License, which permits unrestricted use, distribution, and reproduction in any medium, provided the original author and source are credited. 
For the CCR5 gene mutation study venous blood was collected in Vacuette ACD-B containing test-tubes (Greiner Bio-One, Austria).DNA was extracted from Peripheral Blood Mononuclear Cells (PBMC) using ABI Prism 6100 Nucleic Acid Prep Station (Applied Biosystems, France). CCR5 exon 4 was first amplified by polymerase chain reaction (PCR) using the primer pair 5'-CATTCATGGAGGGCAACTAAATACAT-3' and 5'-GGAGTGAAGGGAG AGTTTGTCAATAA-3' (Genset, Paris, France). Denatured genomic DNA $\left(5 \mathrm{~min} / 94^{\circ} \mathrm{C}\right)$ was amplified for 25 cycles using 1.5 U Taq (Applied Biosystems, Courtaboeuf, France), $0,1 \mathrm{U}$ proofreading Pfu (Stratagene, Amsterdam, the Netherlands), $0.2 \mathrm{mmol} / \mathrm{L}$ dNTP and $0.2 \mathrm{~mol} / \mathrm{L}$ primers $\left(94^{\circ} \mathrm{C}\right.$ for $30 \mathrm{~s}, 55^{\circ} \mathrm{C}$ for $30 \mathrm{~s}$ and $72^{\circ} \mathrm{C}$ for $\left.2 \mathrm{~min}\right)$; then elongation was completed $\left(72^{\circ} \mathrm{C}\right.$ for $\left.7 \mathrm{~min}\right)$. This PCR product was then used as template for amplification of three overlapping segments $\left(94^{\circ} \mathrm{C}\right.$ for $30 \mathrm{~s}, 55^{\circ} \mathrm{C}$ for $30 \mathrm{~s}$ and $72^{\circ} \mathrm{C}$ for $\left.30 \mathrm{~s}\right)$. The primer pair used was 5'-CATTCATGGAGGGCAACTAAATACAT-3' and 5'-GAAGATTCCAGAG AAGAAGCCTATAAAATA-3' for the first part, 5'-ATCTCTGACCTGTTTTTCCTTCTT ACT-3' and 5'-CGAAGCAGAGTTTTTAGGATTCC-3' for the second and 5'-TCCTGC CGCTTGTCA-3' and 5'-GCCCAGGCTGTGT ATGAAAACTAA-3' for the last part [18].

Medical records were used to collect demographic, medical and behavioral characteristics of study participants (age, ethnicity, liver enzymes and ultrasound results, HCV and HDV co-infections, vaccination status, treatment history, alcohol consumption - excessive consumption of alcohol was determines as more then 1 standard drink minimum 2-3 times a week).

\section{Statistical Analysis}

All data were entered and analyzed using SPSS version 16.0. The $p$ value of 0.05 was considered as significant for all tests. To determine the sample size we used the statistical program G-Power for $\alpha=0.05$ and Power $=0.80$ parameters.

Univariate analysis was used for description of demographic and clinical data. The main outcome variable was HBsAg status, predictor variable was having CCR5 mutation, and co-factors were: sex, age, ethnicity, alcohol consumption and HCV and HDV co-infections.

$\chi 2$ Test was used to assess associations between dichotomous variables. Small subgroups were analyzed with Fisher's exact test. Logistic regression was used to identify independent factors of HBsAg persistence.

\section{Results}

\section{Association of HBsAg persistence with demographic factors}

The likelihood of Hepatitis B persistence was 1.3 times higher among males (OR $=1.30 ; 95 \%$ CI 1.09, 1.54). No significant difference was observed between $\mathrm{HbsAg}+$ and HbsAg- groups by age and ethnicity.

\section{Association of $\mathrm{HBsAg}$ persistence with behavioral and medical factors}

The statistically significant association between alcohol consumption and HBsAg persistence was observed. HCV co-infection rate was higher in control group compared to cases $(11.2 \%$ and $6.45 \%$, respectively), although this difference could not reach statistical significance $(\mathrm{p}=0.28) .3 .2 \%$ of $\mathrm{HBsAg}$ positive patients were co-infected with HDV.

None of the study participants had antiviral treatment for the moment of the study or previous history of treatment with antivirals (Table 1).

\section{CCR5 gene mutation frequency}

The overall prevalence of CCR5 receptor mutation was $13.1 \%$ $(\mathrm{n}=37)$. Among controls (HBsAg-) CCR5 receptor mutation was detected in $16.5 \%(n=31)$, in cases - only in $6.4 \%(n=6)$;

Cases were 2.58 times less likely to have CCR5 $\Delta 32$ mutation compared to controls ( $\mathrm{OR}=2.58 ; 95 \% \mathrm{CI} 1.12,5.98)$ (Table 2).

Multivariate analysis revealed CCR5 receptor mutation and alcohol consumption as independent predictors of HBs positivity.

\section{Discussion}

The study revealed that the frequency of hepatitis B persistency among persons with CCR5 mutation was 2.58-times lower compared to persons without CCR5 mutation ( $\mathrm{P}=0.029,95 \%$ CI $1.12,5.97)$. This is in agreement with the results of the studies by Thio et al. [8,9] where it was shown that viral persistence was 1.95 times more common (95\% CI $1.17,3.23 ; \mathrm{p}=0.009)$ in the study subjects with CCR $5+/+$ than among individuals with at least one copy of delta32 mutated CCR5 gene [9].

In other studies such an association has not been demonstrated possibly due to the very low occurrence of the CCR5 delta32 mutation in the specific single ethnic populations studied. One of these studies (Khorramdelazad et al.) has involved 360 subjects from South-East of Iran (60 patients with chronic HBV infection and 300 healthy individuals) where none of the HBV infected patients carried CCR5 delta32 mutation and among the healthy individuals the mutation frequency was as low as $1 \%$ [10-12]. The other studies have been conducted among single ethnic Korean populations where CCR5 delta32 homozygosity or heterozygosity was not found in any of studied Korean patients [12]. No statistically significant associations with HBV susceptibility/persistence with the RANTES -403 and -28 , MCP-1 -2518, CCR2 V64I, CCR5 -2459 and 59029G / 59353T, CXCR4 I138I polymorphisms has been demonstrated in these studies $[11,12]$.

Data opposite to our and similar findings (Thio et al.) were demonstrated by Suneetha et al. [13] where the frequency of heterozygosity of CCR5 delta 32 mutation was higher in chronic hepatitis B patients than in controls. Goel et al. in their recent study were investigating the possible additive impact of CCR5 delta32 mutation to the outcome of the treatment of HBV infection with antiviral drugs Adefovir, Lamivudine and Telbivudine, but they could not demonstrate a significant association of CCR5 delta32 polymorphism with the treatment outcome of patients with chronic HBV infection possibly due to the small size of the sample and the limited duration of the antiviral therapy [14].

All these studies provide controversial data on the role of CCR5 delta32 mutation in the clearance vs. persistence of HBV infection. Further studies including functional studies will clarify the real impact of this particular mutation to the immunological response and the clinical course of HBV infection. This can lead to the possibility of administration of a CCR5 blocking agent along with the conventional antiviral drugs (e.g. nucleoside analogues) to provide higher efficiency towards HBV elimination form the HBV-infected organism. Such an approach would be the analogue to the HIV therapy where CCR5 receptor antagonists are already used in the clinical management of HIV infected persons.

In our study the frequency of Hepatitis B persistency was 1.3-times 
Citation: Kamkamidze G, Kikvidze T, Butsashvili M, Chubinishvili O (2014) Factors Associated with Persistence of Hepatitis B Virus Infection. J Liver 3: 153. doi:10.4172/2167-0889.1000153

Page 3 of 4

\begin{tabular}{|c|c|c|c|c|c|c|c|}
\hline \multirow[t]{2}{*}{ Variable } & \multicolumn{2}{|c|}{ ALL N=282 } & \multicolumn{2}{|c|}{ HBsAg- $N=188$} & \multicolumn{2}{|c|}{ HBsAg+ N=94 } & \multirow[t]{2}{*}{$P$ value } \\
\hline & $\mathrm{N}$ & $\%$ & $\mathrm{~N}$ & $\%$ & $\mathrm{~N}$ & $\%$ & \\
\hline \multicolumn{8}{|l|}{ Sex } \\
\hline Females & 147 & $52.1 \%$ & 110 & $58.5 \%$ & 37 & $39.4 \%$ & 0.0025 \\
\hline Males & 135 & $47.9 \%$ & 78 & $41.5 \%$ & 57 & $60.6 \%$ & \\
\hline \multicolumn{8}{|l|}{ Age } \\
\hline $0-20$ & 27 & $9.6 \%$ & 15 & $8.0 \%$ & 12 & $12.8 \%$ & 0.46 \\
\hline $20-40$ & 118 & $41.8 \%$ & 77 & $41.0 \%$ & 41 & $43.6 \%$ & \\
\hline $40-60$ & 103 & $36.5 \%$ & 71 & $37.8 \%$ & 32 & $34.0 \%$ & \\
\hline$>60$ & 34 & $12.1 \%$ & 25 & $13.2 \%$ & 9 & $9.6 \%$ & \\
\hline \multicolumn{8}{|l|}{ Ethnicity } \\
\hline Georgians & 216 & $76.6 \%$ & 143 & $76.0 \%$ & 73 & $77.7 \%$ & 0.968 \\
\hline Russians/Ukrainians & 24 & $8.5 \%$ & 17 & $9.0 \%$ & 7 & $7.4 \%$ & \\
\hline Azerbaijanis & 23 & $8.2 \%$ & 15 & $8.0 \%$ & 8 & $8.5 \%$ & \\
\hline Armenians & 19 & $6.7 \%$ & 13 & $7.0 \%$ & 6 & $6.4 \%$ & \\
\hline \multicolumn{8}{|l|}{ Alcohol consuming } \\
\hline No & 110 & $39.0 \%$ & 82 & $43.6 \%$ & 28 & $29.8 \%$ & 0.0118 \\
\hline Rarely & 99 & $35.1 \%$ & 67 & $35.6 \%$ & 32 & $34.0 \%$ & \\
\hline Frequently & 73 & $25.9 \%$ & 39 & $20.7 \%$ & 34 & $36.2 \%$ & \\
\hline \multicolumn{8}{|l|}{ HCV co-infection } \\
\hline $\mathrm{HCV}+$ & 27 & $9.6 \%$ & 21 & $11.2 \%$ & 6 & $6.4 \%$ & 0.28 \\
\hline HCV - & 255 & $90.4 \%$ & 167 & $88.8 \%$ & 88 & $93.6 \%$ & \\
\hline \multicolumn{8}{|l|}{ HDV co-infection } \\
\hline $\mathrm{HDV}+$ & 3 & $1.1 \%$ & 0 & $0 \%$ & 3 & $3.2 \%$ & 0.036 \\
\hline HDV - & 279 & $98.9 \%$ & 188 & $100 \%$ & 91 & $96.8 \%$ & \\
\hline
\end{tabular}

Table 1: Frequencies of different factors in study and control groups.

\begin{tabular}{|c|c|c|c|c|c|c|c|c|}
\hline Variable & \multicolumn{2}{|c|}{ All N=282 } & \multicolumn{2}{c|}{ HBsAg- $\mathbf{N}=188$} & \multicolumn{2}{c|}{ HBs Ag+ $=\mathbf{9 4}$} & $\boldsymbol{P}$ value & 95\% Confidence Interval \\
\hline & $\mathrm{N}$ & $\%$ & $\mathrm{~N}$ & $\%$ & $\mathrm{~N}$ & $\%$ & & \\
\hline CCR5 Mutation & & & & & & & & \\
\hline Yes & 37 & $13.1 \%$ & 31 & $16.5 \%$ & 6 & $6.4 \%$ & 0.029 & $1.12-5.97$ \\
\hline No & 245 & $86.9 \%$ & 157 & $83.5 \%$ & 88 & $93.6 \%$ & & \\
\hline
\end{tabular}

Table 2: Frequency of CCR5 $\Delta 32$ in Cases and Controls.

higher in males then in females (OR $=1.30 ; 95 \%$ CI 1.09 to 1.54 ; $\mathrm{P}=0.0025)$. This is consistent with other studies showing association of gender with HBsAg positivity [20].

Multivariate analysis did not confirm gender as the independent risk-factor for HBV infection persistence. Gender is significantly associated with alcohol use (males having higher chance of frequently consuming alcohol). Excessive alcohol consumption is an independent risk-factor for HBV infection by regression analysis.

We could not find the association between patient's age and $\mathrm{HBV}$ infection persistence. Other researches showed association of chronic HBV with patient's age only in those cases, where the age was ascertained at the moment of acquiring infection. Primary infection with Hepatitis B virus causes infection persistence in $1-10 \%$ of cases among adults, while proportion of patients developing chronic HBV after acute infection is much higher among young individuals and ranges from 20\% (among preschool children) to $90-95 \%$ (among newborns) [21].

One of the methods for defining the role of genetic component in the genesis of infectious diseases is to find the difference between immune responses in different ethnic groups exposed to the same exposure. This study did not find the difference in HBV persistence between ethnic groups, unlike some other studies showing association of ethnicity with the risk of chronic HBV infection [22-24].

Non-vaccinated patients had 1.13-times higher rate of Hepatitis
B persistence compared to the vaccinated cases, although statistical significance was not found ( $\mathrm{P}=0.64,95 \%$ CI $0.44,5.82)$.

In conclusion, the study gives clear evidence that genetic factors (CCR5 receptor mutation) play an important role in Hepatitis B virus persistence together with environmental/behavioral factors, such as the alcohol use.

\section{Acknowledgements}

The study was supported by SUNY AIDS International Training Program, Fogarty International Center, and NIH, US, project No 1009228, award No 2892532488 and University Research Program grant No S-GE800-13-GR-122, US Embassy in Georgia.

\section{References}

1. http://www.who.int/csr/disease/hepatitis/whocdscsrlyo20022/en/index3.html

2. Ramezani A, Hasanjani Roshan MR, Kalantar E, Eslamifar A, Banifazl M, et al (2008) Association of human leukocyte antigen polymorphism with outcomes of hepatitis B virus infection. J Gastroenterol Hepatol 23: 1716-1721.

3. Thursz M, Yee L, Khakoo S (2011) Understanding the host genetics of chronic hepatitis B and C. Semin Liver Dis 31: 115-127.

4. Frodsham AJ (2005) Host genetics and the outcome of hepatitis B viral infection. Transpl Immunol 14: 183-186.

5. Thursz MR (1997) Host genetic factors influencing the outcome of hepatitis. $J$ Viral Hepat 4: 215-220.

6. Sanchooli J, Sanadgol N, Kazemi Arababadi M, Kennedy D (2014) CCR5 plays important roles in hepatitis B infection. Viral Immunol 27: 2-6.

7. Ahmadabadi BN, Hassanshahi G, Khoramdelazad H, Mirzaei V, Sajadi SM 
Citation: Kamkamidze G, Kikvidze T, Butsashvili M, Chubinishvili O (2014) Factors Associated with Persistence of Hepatitis B Virus Infection. J Liver 3: 153. doi:10.4172/2167-0889.1000153

et al. (2013) Downregulation of CCR5 expression on the peripheral blood CD8+ T cells of southeastern Iranian patients with chronic hepatitis B infection. Inflammation 36: 136-140.

8. Thio CL, Astemborski J, Thomas R, Mosbruger T, Witt MD, et al. (2008) Interaction between RANTES promoter variant and CCR5Delta32 favors recovery from hepatitis B. J Immunol 181: 7944-7947.

9. Thio CL, Astemborski J, Bashirova A, Mosbruger T, Greer S, et al. (2007) Genetic protection against hepatitis B virus conferred by CCR5Delta32: Evidence that CCR5 contributes to viral persistence. J Virol 81: 441-445.

10. Khorramdelazad H, Hakimizadeh E, Hassanshahi G, Rezayati M, Sendi H, et al. (2013) CCR5 Î" 32 mutation is not prevalent in Iranians with chronic HBV infection. J Med Virol 85: 964-968.

11. Cheong JY, Cho SW, Choi JY, Lee JA, Kim MH, et al. (2007) RANTES, MCP1, CCR2, CCR5, CXCR1 and CXCR4 gene polymorphisms are not associated with the outcome of hepatitis $B$ virus infection: results from a large scale single ethnic population. J Korean Med Sci 22: 529-535.

12. Ahn SH, Kim do Y, Chang HY, Hong SP, Shin JS, et al. (2006) Association of genetic variations in CCR5 and its ligand, RANTES with clearance of hepatitis $\mathrm{B}$ virus in Korea. J Med Virol 78: 1564-1571.

13. Suneetha PV, Sarin SK, Goyal A, Kumar GT, Shukla DK, et al. (2006) Association between vitamin D receptor, CCR5, TNF-alpha and TNF-beta gene polymorphisms and HBV infection and severity of liver disease. J Hepatol 44 856-863.

14. Goel V, Bose PD, Sarma MP, Hazam RK, Das BC, et al. (2013) Chemokine receptor 5 (CCR5) polymorphism in chronic hepatitis $B$ patients treated with three different nucleos(t)ide analogues. Indian J Med Res 137: 1208-1209.

15. Ajuebor MN, Wondimu Z, Hogaboam CM, Le T, Proudfoot AE, et al. (2007) CCR5 deficiency drives enhanced natural killer cell trafficking to and activation within the liver in murine T cell-mediated hepatitis. Am J Pathol 170: 19751988.
16. Liu R, Paxton WA, Choe S, Ceradini D, Martin SR, et al. (1996) Homozygous defect in HIV-1 coreceptor accounts for resistance of some multiply-exposed individuals to HIV-1 infection. Cell 86: 367-377.

17. Samson M, Libert F, Doranz BJ, Rucker J, Liesnard C, et al. (1996) Resistance to HIV-1 infection in caucasian individuals bearing mutant alleles of the CCR-5 chemokine receptor gene. Nature 382: 722-725

18. Kamkamidze G, Capoulade-Metay C, Butsashvili M, Dudoit $Y$, Chubinishvili O et al. (2005) 32-nucleotide deletion, associated with defence against hiv/aids, is a predominant mutation of CCR5 gene in the population of Georgia. Georgian Med News : 74-79.

19. Rehermann B, Lau D, Hoofnagle JH, Chisari FV (1996) Cytotoxic T Iymphocyte responsiveness after resolution of chronic hepatitis B virus infection. J Clin Invest 97: 1655-1665.

20. Blumberg BS, Sutnick AI, London WT, Melartin L (1972) Sex distribution of Australia antigen. Arch Intern Med 130: 227-231.

21. Mahy WB, Compans WR (1996) Immunobiology and pathogenesis of persistent virus infections. Harwood academic publishers.

22. Carrilho FJ, Ono-Nita SK, Cardoso RA, Cancado EL, Pinho JR, et al. (2005) A prospective study of hepatitis $B$ virus markers in patients with chronic HBV infection from Brazilian families of Western and Asian origin. Braz J Med Biol Res 38: 1399-1408.

23. Custer B, Sullivan SD, Hazlet TK, lloeje U, Veenstra DL, et al. (2004) Global epidemiology of hepatitis B virus. J Clin Gastroenterol 38: S158-168.

24. Tong MJ, Weiner JM, Ashcavai MW, Redeker AG, Comparini S, et al. (1979) A comparative study of hepatitis $B$ viral markers in the family members of Asian and non-Asian patients with hepatitis B surface antigen-positive hepatocellula carcinoma and with chronic hepatitis B infection. J Infect Dis 140: 506-512. 